\title{
Polymorphism of BTN and GHR genes and its impact on bulls' breeding value for milk production traits
}

\author{
J. Komisarek ${ }^{1}$ and Z. Dorynek \\ August Cieszkowski Agricultural University, \\ Department of Cattle Breeding \\ Wojska Polskiego 71 A, 60-625 Poznań, Poland
}

(Received 10 March 2003; revised version 30 June 2003; accepted 28 October 2003)

\begin{abstract}
The aim of the study was to estimate the effect of the butyrophilin (BTN) and growth hormone receptor (GHR) gene polymorphisms on the breeding value of genotyped AI bulls for milk production traits. A total of 131 Holstein-Friesian bulls were analysed. The following allele frequencies have been found: $0.88(\mathrm{~L})$ and $0.12(\mathrm{~A})$ at the BTN locus, and $0.85(\mathrm{~S})$ and $0.15(\mathrm{G})$ at the GHR locus. The effect of genotype on milk yield and composition was tested in the group of $101 \mathrm{AI}$ proven bulls. Because the number of A/A and G/G animals was very low, the gene-trait association analysis was reduced to the comparison of two remaining genotypes at each locus. No significant association has been found. However, bulls with the L/L genotype at the BTN gene were characterized by a higher breeding value for milk fat content than animals with the $\mathrm{L} / \mathrm{A}$ genotype $(\mathrm{P} \leq 0.1)$.
\end{abstract}

KEY WORDS: BTN, GHR, milk traits, breeding value, cattle

\section{INTRODUCTION}

Most economically important traits in cattle are quantitative in nature. The observed phenotypes result from the combined action of many genes and environmental factors. Although genes influencing these traits still remain unknown, a number of potential candidate genes have been selected.

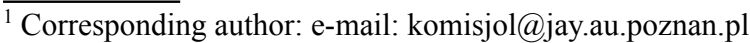


The somatotropic axis, primarily consisting of the growth hormone (GH) and its receptor (GHR), contains the most promising candidates for milk production traits in cattle. It has been well established that GH stimulates the protein and energy metabolism (Breier, 1999) and is important for mammary growth and development (Sejrsen et al., 1999). The exogenous somatotropin treatment dramatically increases milk yield in cows and other dairy ruminants (Bauman and Vernon, 1993). This demonstrates the critical role of GH in the regulation of lactation processes. Because the first step in the biological action of the growth hormone is its binding to the specific cell surface receptor, GHR can be regarded as a candidate gene for milk related traits.

Butyrophilin (BTN) is another gene attracting attention, which may be involved in the milk secretion. Many characteristics suggest its possible role, especially in the secretion of milk lipids. Butyrophilin is a transmembrane glycoprotein, specifically expressed in the mammary epithelial cells during late pregnancy and lactation (Franke et al., 1981; Ogg et al., 1996; Aoki et al., 1997). It is also the major protein component of the membrane surrounding fat droplets of milk (Mather et al., 1980). The knock-out of the BTN gene in mice considerably disrupts milk lipid secretion (Ogg et al., 2000). Additionally, butyrophilin is structurally related to proteins of the immune system, which may suggest its possible immunologic function (Vernet et al., 1993; Taylor et al., 1996b).

The aim of the present study was to analyse the relationships between the polymorphism in the coding sequences of BTN and GHR, and the milk traits in cattle, based on the breeding values of genotyped AI bulls. The A $\rightarrow G$ point mutation in exon 8 resulting in Lys $\rightarrow$ Arg amino acid substitution (L and A alleles) (Taylor et al., 1996a) was analysed for the butyrophilin gene, whereas for the growth hormone receptor gene, it was the $\mathrm{A} \rightarrow \mathrm{G}$ mutation in exon 10 causing amino acid change from Ser to Gly (S and G alleles) (Ge et al., 2000).

\section{MATERIAL AND METHODS}

The study included 131 Holstein-Friesian bulls. Among them, 101 were AI proven bulls with estimated on the national scale official breeding values (Żarnecki et al., 2001) for milk production traits (milk, fat and protein yields, fat and protein contents).

Genome DNA was isolated from blood leukocytes using the MasterPure DNA Purification Kit for Blood (Epicentre), or from semen as described Lucy et al. (1993).

Primers for PCR amplification (MWG Biotech) were designed using the Primer3 program (http://www.genome.wi.mit.edu/cgi-bin/primer/primer3_www.cgi) on the basis of gene sequences available in the GenBank (accession numbers: BTN - Z93323, GHR - X70041): 
BTN forward primer: 5'- TGGAGCTCTATGGAAATGGG - 3' BTN reverse primer: 5'- ACCCTTTGGGTT TTCTGCTT - 3' GHR forward primer: 5'- GAATAAGACTGGGAACCCCC - 3' GHR reverse primer: 5'- GGTCTGTGCTCACATAGCCA - 3'

PCR for both fragments were performed in a reaction volume of $25 \mu \mathrm{l}$ containing 20-50 ng of genomic DNA, 1 unit of Taq DNA polymerase (Fermentas), $1 \mu \mathrm{M}$ of each primer, $75 \mathrm{mM}$ Tris- $\mathrm{HCl}(\mathrm{pH} 8.8), 20 \mathrm{mM}\left(\mathrm{NH}_{4}\right)_{2} \mathrm{SO}_{4}, 0.01 \%$ Tween 20, $2 \mathrm{mM} \mathrm{MgCl}$, and $200 \mu \mathrm{M}$ of each dNTPs. Amplifications were carried out using a TGradient thermocycler (Biometra) as follows: $94^{\circ} \mathrm{C}$ for $5 \mathrm{~min} ; 30$ cycles consisting of $30 \mathrm{~s}$ at $94^{\circ} \mathrm{C}, 40 \mathrm{~s}$ at $59^{\circ} \mathrm{C}(\mathrm{BTN})$ or $59.5^{\circ} \mathrm{C}(\mathrm{GHR})$ and $30 \mathrm{~s}$ at $72^{\circ} \mathrm{C}$; $72^{\circ} \mathrm{C}$ for $5 \mathrm{~min}$. The amplified fragments of BTN and GHR genes $(15 \mu \mathrm{l}$ of PCR products) were digested at $37^{\circ} \mathrm{C}$ for $2 \mathrm{~h}$ with 10 units of HaeIII and AluI restriction enzymes (Fermentas), respectively, and next subjected to electrophoretic separation in $2.5 \%$ agarose gel (BASICA LE GQT, Prona).

The genotype effect on breeding value (BV) for milk traits was estimated assuming the following univariate model (SAS, 1989):

where:

$$
\mathrm{y}_{\mathrm{ij}}=\mu+\mathrm{g}_{\mathrm{i}}+\mathrm{e}_{\mathrm{ij}}
$$

$\mathrm{y}_{\mathrm{ij}}$ - breeding value for production trait of $\mathrm{ij}^{\text {th }}$ sire

$\mu$ - overall mean

$g_{i} \quad$ fixed effect of $i^{\text {th }}$ genotype

$\mathrm{e}_{\mathrm{ij}}-$ random error connected with breeding value of $\mathrm{ij}^{\text {th }}$ sire

\section{RESULTS}

The PCR reaction yielded a 780 bp long BTN gene fragment. Five HaeIII restriction sites were found in the $\mathrm{L}$ allele, at positions 162, 175, 185, 556 and 693. In A allele, an additional restriction site at position 218 was present (Figure 1). The $377 \mathrm{bp}$ long PCR product of the GHR gene, digested with the AluI restriction enzyme, leads to three $(59,150$ and $168 \mathrm{bp})$ and four $(50,59,100$ and $168 \mathrm{bp})$ bands in the $\mathrm{G}$ and $\mathrm{S}$ alleles, respectively (Figure 2).

Among the 131 bulls examined, $101 \mathrm{~L} / \mathrm{L}, 28 \mathrm{~L} / \mathrm{A}$ and $2 \mathrm{~A} / \mathrm{A}$ genotypes at the BTN locus were detected. This gives frequencies of 0.88 and 0.12 for $\mathrm{L}$ and A alleles, respectively. Very similar results were obtained for the GHR locus, with the following genotype and allele frequencies: $\mathrm{S} / \mathrm{S}-0.73, \mathrm{~S} / \mathrm{G}-0.24, \mathrm{G} / \mathrm{G}-0.03$, $\mathrm{S}-0.85, \mathrm{G}-0.15$.

The genotype effects on BV were tested in the group of 101 AI proven bulls. Because of their very low number, animals with A/A (2 individuals) and 


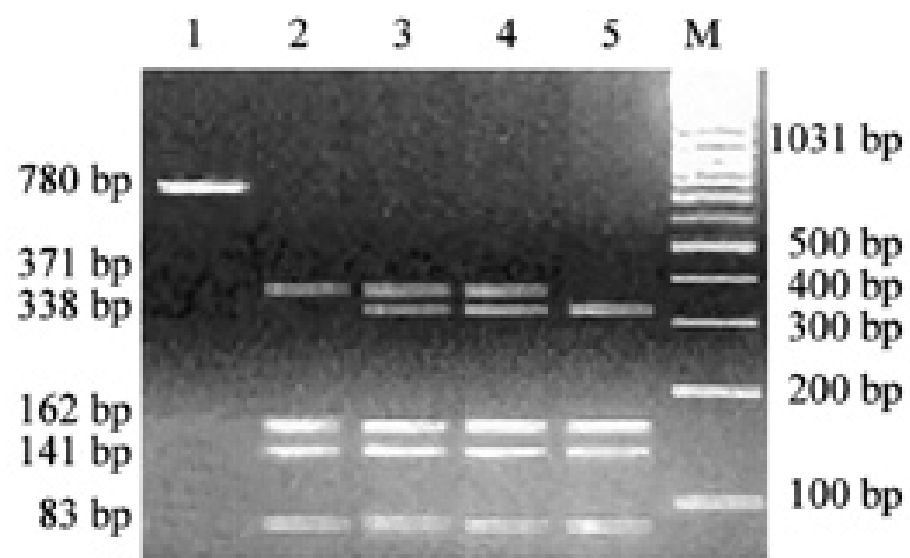

Figure 1. BTN genotyping by PCR-RFLP method. Lane 1 - undigested amplification product; lane 2 - LL genotype (10 bp and $13 \mathrm{bp}$ bands not seen on the gel); lanes 3, 4 - LA genotype (10 bp, $13 \mathrm{bp}$ and $33 \mathrm{bp}$ bands not seen on the gel); lane 5 - AA genptype (10 bp, $13 \mathrm{bp}$ and $33 \mathrm{bp}$ bands not seen on the gel); M - DNA marker: GeneRuler ${ }^{\mathrm{TM}}$ DNA Ladder Mix (Fermentas)

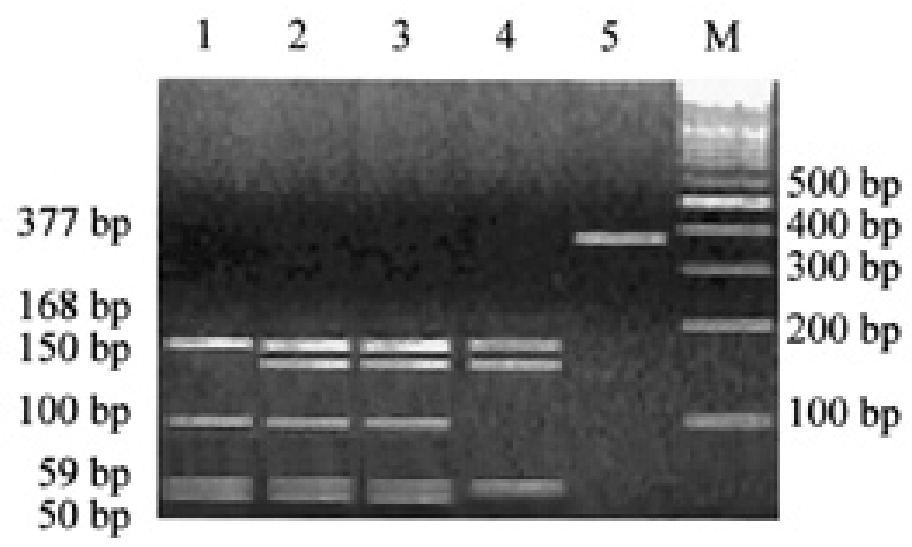

Figure 2. GHR genotyping by PCR-RFLP method. Lane 1 - SS genotype; lanes 2, 3 - SG genotype; lanes 4 - GG genotype; lane 5 - undigested amplification product; M - DNA marker: GeneRuler ${ }^{\mathrm{TM}}$ DNA Ladder Mix (Fermentas)

$\mathrm{G} / \mathrm{G}$ (2 individuals) genotypes were excluded from the calculations. Thus, the statistic analysis was reduced to the comparison of two genotypes for each locus. The obtained results are presented in Table 1. No significant association has been found. Bulls with the L/L genotype at the BTN locus, however, were characterized by a higher breeding value for milk fat content than animals with the L/A genotype. 
TABLE 1

Least square means for breeding values of analysed AI bulls with different BTN and GHR genotypes

\begin{tabular}{|c|c|c|c|c|}
\hline \multirow{3}{*}{ Trait } & \multicolumn{4}{|c|}{ Genotype } \\
\hline & \multicolumn{2}{|c|}{ BTN } & \multicolumn{2}{|c|}{ GHR } \\
\hline & $\begin{array}{c}\mathrm{L} / \mathrm{L} \\
\mathrm{n}=78\end{array}$ & $\begin{array}{c}\mathrm{L} / \mathrm{A} \\
\mathrm{n}=21\end{array}$ & $\begin{array}{c}\mathrm{S} / \mathrm{S} \\
\mathrm{n}=73\end{array}$ & $\begin{array}{c}\mathrm{S} / \mathrm{G} \\
\mathrm{n}=26\end{array}$ \\
\hline Milk yield, kg & 848.15 & 914.41 & 863.45 & 890.96 \\
\hline Fat yield, kg & 32.42 & 31.50 & 30.85 & 33.24 \\
\hline Protein yield, kg & 26.87 & 26.34 & 27.06 & 26.22 \\
\hline Fat content, $\%$ & $-0.03^{*}$ & $-0.10^{*}$ & -0.05 & -0.04 \\
\hline Protein content, $\%$ & -0.01 & -0.04 & -0.02 & -0.03 \\
\hline
\end{tabular}

" columns with the same superseript differ at $\mathrm{P} \leq 0.1$

\section{DISCUSSION}

The BTN allele frequencies estimated in the present study ( 0.88 and 0.12 ) were very similar to the 0.875 and 0.125 (Taylor et al., 1996a) and to the 0.85 and 0.15 (Husaini et al., 1999) previously reported for Holstein cattle. The high frequency of the L allele suggests that this variant might be favoured by the selection on milk performance. The physiological and biochemical studies also indicate the role of butyrophilin in the milk production. In particular, BTN is considered to be involved in the milk fat secretion.

In cattle, as in many other species, triglycerides synthesized in mammary epithelial cells are secreted to the milk fluid as lipid droplets surrounded by the apical plasma membrane by the "budding-off" process. It has been proposed that the budding of the droplets at the cell surface is initiated by interactions between proteins associated with the intracellular fat and the cytoplasmic C-terminal domain of butyrophilin, with the participation of other proteins (Mather and Keenan, 1998; Murphy and Vance, 1999). The BTN polymorphism analysed in this study is located within the highly conserved region (known as B30.2 or rfp) of the C-domain that is probably involved in the protein-protein interactions (Jack and Mather, 1990; Ishii et al., 1995). Thus, the Lys/Arg substitution may cause the changes in the binding affinity and, as the result of this, influence the fat secretion process.

BTN has been mapped on the bovine chromosome 23 (Taylor et al., 1996a). Extensive studies on the identification of quantitative trait loci (QTLs) in cattle brought numerous reports indicating the presence of putative genes affecting milk production in the same genome region. Some of the detected QTLs influence milk fat yield and content (Ashwell et al., 1997; Zhang et al., 1998; Plante et al., 2001). Butyrophilin is one of the possible causative genes for these traits, although other closely located loci, including MHC, should also be taken into consideration. 
The structure and sequence of the bovine BTN gene is well known (Davey et al., 1997; Seyfert and Lüthen, 1998). A number of polymorphic forms have been identified (Taylor et al., 1996a; Husaini et al., 1999; Zegeye et al., 1999). However, their impact on production traits in cattle has not been examinated extensively. The analysis carried out in the present study consisted in the comparison of the breeding value of bulls carrying the LL and LA genotypes. No significant result has been found for any trait considered. However, due to very limited statistic analysis, the conclusion that the tested mutation does not influence the milk performance seems to be premature, the more as for one trait (fat percent in the milk) the difference was close to the significance level of $\mathrm{P} \leq 0.05$. On the other hand, experiment of Zegeye et al. (1999) also did not revealed the relationship between the exon 8 HaeIII polymorphism and the milk production. They analysed, using the grand-daughter design, 5 RFLPs within BTN as markers for milk yield and composition. The only one significant association found in their study was between the intronic polymorphism and the milk protein percentage.

The growth hormone receptor, belonging to the somatptropic axis, is considered to have a major effect on both milk and the growth performance in cattle. The sequence variations within the regulatory region of GHR were shown to be associated with milk production (Aggrey et al., 1998, 1999). It was also found that the $\mathrm{T} \rightarrow$ A mutation in exon 8 resulting in Phe $\rightarrow$ Tyr amino acid substitution influences milk yield and composition (Blott et al., 2003).

In this study, the AluI polymorphism in exon 10 has been examined. The $\mathrm{S}$ allele was shown to occur with the much higher frequency (0.85) than the G allele $(0.15)$. That not necessarily means that the $G$ variant is eliminated by selection for the milk production, as the similar frequency of 0.22 was obtained for the beef Angus breed (Ge et al., 2000). The association analysis failed to reveal any significant relationship between GHR polymorphism and the bulls' breeding value for milk related traits. However, as in the case of the BTN gene, only two genotypes were compared. Thus, since the statistic analysis was limited, the obtained results are not entirely reliable.

The findings presented in this paper indicate that the analysed here BTN and GHR genes polymorphism is not associated with the milk related traits in cattle. However, the above conclusion should be confirmed in further investigations, taking into consideration all possible genotypes at both loci. The special emphasis should be placed on the potential effect of the BTN polymorphism on the fat content in the milk. 


\section{REFERENCES}

Aggrey S.E., Yao J., Sabour M.P., Lin C.Y., Zadworny D., Hayes J.F., Kuhnlein U., 1999. Markers within the regulatory region of the growth hormone receptor gene and their associations with milk-related traits in Holsteins. J. Hered. 90, 148-151

Aggrey S.E., Yao J., Zadworny D., Hayes J.F., Kuhnlein U., 1998. Synergism between genetic markers in the growth hormone and growth hormone receptor genes in influencing milk related traits in Holsteins. Proceedings of $6^{\text {th }}$ World Congress on Genetics Applied to Livestock Production, 26, 281-284

Aoki N., Ishii T, Ohira S., Yamaguchi Y., Negi M., Adachi T., Nakamura R., Matsuda T., 1997. Stage specific expression of milk fat globule membrane glycoproteins in mouse mammary gland: comparison of MFG-E8, butyrophilin, and CD36 with a major milk protein, $\kappa$-casein. Biochim. Biophys. Acta 1334, 182-190

Ashwell M.S., Rexroad C.E. Jr., Miller R.H., VanRaden P.M., Da Y., 1997. Detection of loci affecting milk production and health traits in an elite US Holstein population using microsatellite markers. Anim. Genet. 28, 216-222

Bauman D.E., Vernon R.G., 1993. Effects of exogenous bovine somatotropin on lactation. Annu. Rev. Nutr. 13, 437-461

Blott S., Kim J.-J., Moisio S., Schmidt-Küntzel A., Cornet A., Berzi P., Cambisano N., Ford C., Grisart B., Johnson D., Karim L., Simon P., Snell R., Spelman R., Wong J., Vilkki J., Georges M., Farnir F., Coppieters W., 2003. Molecular dissection of a quantitative trait locus: A phenylalanine-to tyrosine substitution in the transmembrane domain of the bovine growth hormone receptor is associated with a major effect on milk yield and composition. Genetics 163, 253-266

Breier B.H., 1999. Regulation of protein and energy metabolism by the somatotropic axis. Domest. Anim. Endocrinol. 17, 209-218

Davey H.W., Ogg S.L., Husaini Y., Snell R.G., Korobko I.V., Mather I.H., Wilkins R.J., 1997. Structure and sequence of the bovine butyrophilin gene. Gene 199, 57-62

Franke W.W., Heid H.W., Grund C., Winter S., Freudenstein C., Schmid E., Jarasch E.D., Keenan T.W., 1981. Antibodies to the major insoluble milk fat globule membrane-associated protein: specific location in apical regions of lactating epithelial cells. J. Cell Biol. 89, 485-494

Ge W., Davis M.E., Hines H.C., Irvin K.M., 2000. Single nucleotide polymorphisms detected in exon 10 of the bovine growth hormone receptor gene. J. Anim. Sci. 78, 2229-2230

Husaini Y., Wilkins R.J., Davey H.W., 1999. Identification of five point mutations, including an AluI RFLP, in the bovine butyrophilin gene. Anim. Genet. 30, 400-401

Ishii T., Aoki N., Noda A., Adachi T., Nakamura R., Matsuda T., 1995. Carboxy-terminal cytoplasmic domain of mouse butyrophilin specifically associates with a $150-\mathrm{kDa}$ protein of mammary epithelial cells and milk fat globule membrane. Biochim. Biophys. Acta 1245, 285-292

Jack L.J., Mather I.H., 1990. Cloning and analysis of cDNA encoding bovine butyrophilin, an apical glycoprotein expressed in mammary tissue and secreted in association with the milk-fat globule membrane during lactation. J. Biol. Chem. 265, 14481-14486

Lucy M.C., Hauser S.D., Eppard P.J., Krivi G.G., Clark K.J., Bauman D.E., Collier R.J., 1993. Variants of somatotropin in cattle: Gene frequencies in major dairy breeds and associated milk production. Domest. Anim. Endocrinol. 10, 325-333

Mather I.H., Keenan T.W., 1998. Origin and secretion of milk lipids. J. Mammary Gland Biol. 3, 259-273

Mather I.H., Tamplin C.B., Irving M.G., 1980. Separation of the proteins of bovine milk-fat-globule membrane by electrofocusing with retention of enzymatic and immunological activity. Eur. J. Biochem. 110, 327-336 
Murphy D.J., Vance J., 1999. Mechanisms of lipid-body formation. Trends Biochem. Sci. 24, 109-115

Ogg S.L., Dobbie L., Smith A.J.H., Mather I.H., 2000. Ablation of mouse butyrophilin gene by homologous recombination disrupts the regulated secretion of milk-lipid droplets from mammary epithelial cells. Mol. Biol. Cell 11, 1535 (Abstr.)

Ogg S.L., Komaragiri M.V.S., Mather I.H., 1996. Structural organization and mammary-specific expression of the butyrophilin gene. Mamm. Genome 7, 900-905

Plante Y., Gibson J.P., Nadesalingam J., Mehrabani-Yeganeh H., Lefebvre S., Vandervoort G., Jansen G.B., 2001. Detection of quantitative trait loci affecting milk production traits on 10 chromosomes in Holstein cattle. J. Dairy Sci. 84, 1515 - 1524

SAS, 1989. SAS/STAT User's Guide, Version 6, $4^{\text {th }}$ Edition. SAS Inst., Inc., Cary, NC

Sejrsen K., Purup S., Vestegaard M., Weber M.S., Knight C.H., 1999. Growth hormone and mammary development. Domest. Anim. Endocrinol. 17, 117-129

Seyfert H.-M., Lüthen F., 1998. The structure of the bovine butyrophilin encoding gene differs grossly from mouse concering promoter localization and exon organization of the S-untranslated region. Proceedings of $6^{\text {th }}$ World Congress on Genetics Applied to Livestock Production, 25, 51-54

Taylor C., Everest M., Smith C., 1996a. Restriction fragment length polymorphism in amplification products of the bovine butyrophilin gene: assignment of bovine butyrophilin to bovine chromosome 23. Anim. Genet. 27, 183-185

Taylor M.R., Peterson J.A., Cariani R.L., Couto J.R., 1996b. Cloning and sequence analysis of human butyrophilin reveals a potential receptor function. Biochim. Biophys. Acta 1306, 1-4

Vernet C., Boretto J., Mattei M.G., Takahashi M., Jack L.J., Mather I.H., Rouquier S., Pontarotti P., 1993. Evolutionary study of multigenetic families mapping close to the human MHC class I region. J. Mol. Evol. 37, 600-612

Zegeye A., Ashwell M., Ogg S., Rexroad C., Mather I.H., 1999. RFLP markers in the bovine butyrophilin gene. Anim. Genet. 30, 385-386

Zhang Q., Boichard D., Hoeschele I., Ernst C., Eggen A., Murkve B., Pfister-Genskow M., Witte L.A., Grignola F.E., Uimari P., Thaller G., Bishop M.D., 1998. Mapping quantitative trait loci for milk production and health of dairy cattle in a large outbred pedigree. Genetics 149, 1959-1973

Żarnecki A., Jagusiak W., Czaja H., Trela J., 2001. Sire evaluation for dairy production and type traits (in Polish). Annual Report, Research Institute of Animal Production (IZ) Kraków, Vol. 22, ISSN 0867-1249

\section{STRESZCZENIE}

\section{Polimorfizm genów BTN i GHR oraz jego wpływ na wartość hodowlaną buhajów dla cech mleczności}

Celem pracy było określenie wpływu polimorfizmu w genie butyrofiliny (BTN) i receptora hormonu wzrostu (GHR) na wartość hodowlaną buhajów dla cech mleczności. Analizą objęto 131 buhajów rasy holsztyńsko - fryzyjskiej. Uzyskano następujące frekwencje alleli: 0,88 (L) i 0,12 (A) w locus BTN oraz 0,85 (S) i 0,15 (G) w locus GHR. Wpływ genotypu na wydajność i skład mleka szacowano w grupie 101 buhajów reprodukcyjnych. Ponieważ liczba osobników AA i GG była bardzo mała, analiza asocjacji między genem a cechą ograniczała się jedynie do porównania dwóch pozostałych genotypów w każdym locus. Nie wykryto żadnej istotnej zależności. Wartość hodowlana buhajów o genotypie L/L w genie BTN dla zawartości tłuszczu w mleku była jednak wyższa niż buhajów o genotypie $\mathrm{L} / \mathrm{A}(\mathrm{P} \leq 0.1)$. 